\title{
A trajetória histórica do "social"
}

\author{
The historical pathway of the word "social"*
}

Victor Strazzeri**

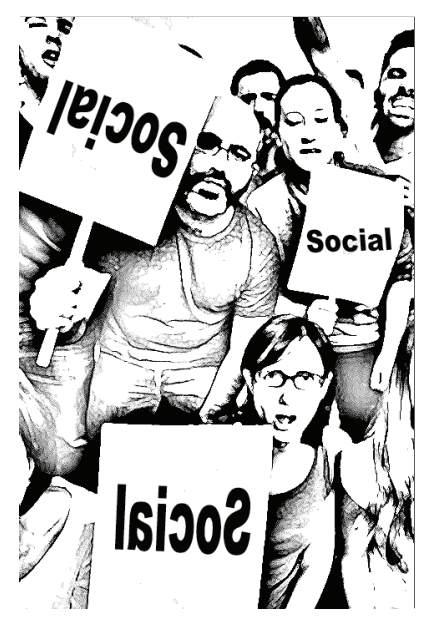

A sociedade pretende 'eliminar todos os inconvenientes' que a atormentam? Muito bem: basta-lhe eliminar os termos inconvenientes, alterar a linguagem e dirigir-se à Academia, encomendando-lhe uma nova edição do seu dicionário!

Karl Marx, A miséria da filosofia

Resumo: Este artigo trata dos diferentes sentidos que a palavra "social" assumiu à luz de alguns momentos-chave das lutas de classes desde meados do século XIX. Com base nessa perspectiva histórico-crítica, analisamos a substantivação do adjetivo "social" e a imputamos à ascensão do movimento operário e à emergência da "questão social". Em seguida, discutimos a contraposição entre a "sociedade" e a "comunidade", cujo pano de fundo é o processo de "decadência ideológica da burguesia" e a reabilitação do passado feudal e dos ideais aristocráticos após 1848 por pensadores como A. de Tocqueville e F. Tönnies.

Palavras-chave: Social. "Questão social”. Decadência ideológica da burguesia. Comunidade.

Abstract: This article deals with the different senses the word "social" has taken at some fundamental moments of the class struggles since the middle of the nineteenth century. Based on that historical and

* A gestação deste artigo se deu nos marcos do Programa de Pós-Graduação em Serviço Social da Universidade Federal do Rio de Janeiro e é dedicado aos docentes e colegas que, generosamente, debateram suas premissas e incentivaram sua confecção.

** Graduado em Ciências Sociais pela PUC-SP, mestre em Serviço Social pela Escola de Serviço Social da UFRJ/Rio de Janeiro/RJ, Brasil, doutorando em Ciência Política na Universidade Livre de Berlim/Alemanha. E-mail: victorstrazzeri@gmail.com. 
critical perspective, we analyzed the transformation of the adjective "social" into a noun, and we related it to the rising of the workers' movement and to the emergence of the "social issue". Then we discussed the opposition between "society" and "community". The background of such opposition is the process of "ideological decadence of the bourgeoisie" and the rehabilitation of the feudal past and aristocratic ideals by thinkers as A. de Tocqueville and F. Tönnies after 1848.

Keywords: Social. "Social issue". Ideological decadence of the bourgeoisie. Community.

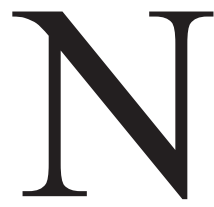

o dizer do jovem Marx: "Ser radical é agarrar as coisas pela raiz. Mas, para o homem, a raiz é o próprio homem" (Marx, 2005, p. 151). E a raiz das palavras? No domínio da gramática ou da linguística tradicionais trata-se de seu radical. Neste artigo procuraremos demonstrar como o exame das palavras segundo sua forma de análise tradicional pode se mostrar uma iniciativa reveladora, mas que ampliada por uma ida à raiz ontológica, ao ser social, torna-se ainda mais fecunda.

Termo-chave para o campo do Serviço Social é "questão social" que, a despeito da carga ideológica que a acompanha, é uma categoria fundante. $\mathrm{Na}$ bibliografia consagrada à área, essa noção é de difícil tematização, já que se por um lado alguns dos pensadores referência do Serviço Social habilmente a desconstroem (José Paulo Netto, Marilda Iamamoto etc.), relegando o termo para a constrição do entre aspas, ainda assim não o descartam. Ao contrário, se apropriam do termo "questão social" e trazem-no para o campo dos estudos críticos no âmbito de um esforço de apreensão das mediações necessárias para a compreensão histórica do Serviço Social. A lição metodológica é precisa:

[...] a apreensão da particularidade da gênese histórico-social da profissão nem de longe se esgota na referência à "questão social" tomada abstratamente; está hipotecada ao concreto tratamento desta num momento muito específico do processo da sociedade burguesa constituída, aquele do trânsito a idade do monopólio. (Netto, 2001, p. 18; grifos nossos)

Há, portanto, uma "questão social" tomada abstratamente e uma "questão social" após sua crítica materialista, que se levada a bom termo desvela o conteúdo efetivo que o termo (liberto das aspas) oculta. Ir à raiz da noção citada é 
“tomar a 'questão social' como problemática configuradora de uma totalidade processual específica, é remetê-la concretamente à relação capital/trabalho - o que significa, liminarmente, colocar em xeque a ordem burguesa" (Idem, p. 32).

Importante questão para o campo do Serviço Social é a difícil posição em que se colocam tanto pensadores quanto operadores desta área ao erguê-la sobre a sua negação/superação. Estas circunstâncias exigem um esforço permanente de busca das mediações que permitam tematizar o Serviço Social para além de uma adesão irrestrita ao seu sentido conservador, indutor de coesão social, mas igualmente para além de seu rechaço completo como mera negatividade.

Pareceu-nos oportuno produzir uma pequena intervenção que possa compor esse esforço de construção de mediações. Acreditamos que a elucidação do percurso histórico do termo "social" - dotado de caminho relativamente independente, mas intrinsecamente ligado com aquele trilhado pela expressão "questão social" - pode oferecer alguns elementos para compreender a gênese e o devir histórico desta última.

No campo das ciências humanas o vocábulo "social" figura já na denominação de alguns de seus principais ramos, como a Ciência e o Serviço Sociais. Nos marcos dessas áreas, conceitos fundantes, como "ação social", "classe social", "assistência social" e "política social", são por ele acompanhados. Se nos ativermos à premissa básica desses domínios científicos - isto é, o estudo e a intervenção sobre a realidade social —, podemos supor que o uso reiterado do termo se justifica pela relação desses saberes com o homem enquanto ser que se reproduz e se desenvolve necessariamente em sociedade. Tal característica intrínseca emprestaria a toda ciência ou campo do saber relativos ao homem em sua convivência com outros homens a alcunha de "social".

Mas aqui já chegamos a um primeiro impasse. Que o homem vive e se desenvolve em grupos de indivíduos de diversas magnitudes e com características diversas, é difícil negar. Mas que ele é um ser intrinsecamente social, incapaz de viver fora do âmbito coletivo, não constitui um consenso. Desde o princípio da era burguesa — não por acaso — coloca-se em questão o vínculo 
necessário homem-sociedade, não faltando defesas do caráter intrinsecamente autônomo e autocentrado do indivíduo. A mais célebre dessas iniciativas é o Robinson Crusoé (1719), de William Defoe, relato das desventuras de um náufrago em uma ilha deserta, para o qual o convívio com outros seres humanos é tido como desejável, mas inteiramente dispensável.

O caráter ficcional da obra de Defoe depõe de forma alguma contra seu estatuto de retrato fiel da concepção de homem que se tornava predominante nos séculos XVII e XVIII na Inglaterra, e que Marx denominou o "ponto de vista da economia política". ${ }^{1}$ Trata-se das "robinsonadas", isto é, a generalização da competição capitalista entre os indivíduos para uma condição humana intrínseca, desprovida de historicidade. Nas palavras de Marx, tratar-se-ia:

[...] da antecipação da "sociedade civil", em preparação desde o século XVI e dando enormes passos rumo a sua maturação no XVIII. Nessa sociedade de livre competição, o indivíduo aparece desligado dos laços naturais etc. que em períodos históricos anteriores faziam dele um apêndice de um conglomerado humano definido e limitado. (Marx, 1973, p. 83; tradução do autor)

No âmbito das ciências humanas, a absolutização da esfera individual ainda se faz presente e com especial força nesta quadra histórica chamada neoliberal, que reabilitou o individualismo possesivo, a competição e a exaltação do mercado (o que mantém vigente o recurso à "robinsonada" e sua crítica por Marx). Assim, se o momento histórico-concreto se caracteriza pela ofensiva neoliberal e pelo refluxo do movimento operário, compreende-se que a noção de uma sociabilidade intrínseca ao homem não deverá ser hegemônica no plano da ideologia e tampouco no da linguagem (supondo aqui que a esfera da linguagem seja, em termos relativos, subalterna à da ideologia).

1. Assim, Hobbes (1994, p. 106) descreve no Leviathan (1651) o homem antes de tudo como um ser antissocial, intrinsecamente competitivo e incapaz de viver em sociedade, senão sob o jugo de um poder superior instituído por um contrato que limite as ambições e demais impulsos violentos e egoístas dos homens. Locke também assevera uma liberdade original irrestrita para o homem no seu Segundo tratado sobre o governo de 1689, de acordo com o qual a sociedade não é condição básica da vida humana. Para ele, a virtude da vida social seria, acima de tudo, assegurar o respeito à propriedade privada, esta sim intrínseca ao homem em seu estado de natureza (cf. Locke, 2001, p. 468). 
Isto nos leva a crer que o termo "social", de uso tão frequente, assume necessariamente significados diferentes para aqueles que o empregam, ainda que isto não esteja explícito de imediato. Sustentamos que, de pronto, ao menos dois campos claramente opostos se delimitam a partir das perspectivas ontológicas antagônicas que, de um lado, descrevem o homem como intrinsecamente social e, de outro, como mônada autossuficiente (ressaltando que nem toda visão se reduz a uma destas concepções). Assim, quando se utiliza o adjetivo "social" há necessariamente uma cisão de sentido, já que sociedade é, para uns, o meio necessário no qual se dá a vida humana e, para outros, uma construção contingente com um propósito específico de existência.

E se há um corte claro no âmbito dos fundamentos ontológicos dos discursos, também há outro - que não necessariamente reproduz o primeiro - que opõe campos antagônicos do discurso político. Quando examinamos, ainda que superficialmente, o vocabulário empregado pela literatura crítica ("transformação social", "lutas sociais", "movimentos sociais") frente à conservadora ("caos social", "revolta social", "convulsão social"), percebemos uma mudança de sentido, mas também um deslocamento valorativo.

Nesses usos em particular, devemos atentar para o fato de que nem todo "social" significa "aquilo que é relativo à sociedade". E isto se dá em ambos os extremos do espectro ideológico, já que se com a expressão "movimento social" não se pretende fazer referência a um movimento da sociedade, "revolta social" tampouco se refere a uma revolta desta. Que o "movimento" e a "revolta" se dão na sociedade é uma tautologia, por que então adjetivá-los como "sociais"? Necessariamente, pois o termo social as qualifica num outro sentido, revestindo os termos com tonalidade política. "Movimento social" é uma ação coletiva de um setor descontente da sociedade com vistas a sua transformação em algum grau; "revolta social", por sua vez, também não faz referência ao todo da sociedade, já que provavelmente exclui os bons cidadãos que utilizam tal expressão. ${ }^{2}$

Assim, a forma de adjetivo de que se reveste o termo "social", em todos os empregos enumerados anteriormente, oculta um outro conjunto de significados

2. É possível até que remeta ao mesmo agrupamento de descontentes pertencentes ao "movimento", imputando-lhe, todavia, um caráter negativo em virtude da ruptura com a ordem. 
que a palavra incorpora, e que se liga a sua manifestação enquanto substantivo. Atentemos para essa diferenciação, pois nos dá a chave para elucidar a polissemia nem sempre manifesta da palavra "social".

Segundo o Dicionário Houaiss da língua portuguesa, o adjetivo "social" denomina algo "concernente à sociedade" ou que é "relativo à comunidade, ao conjunto dos cidadãos de um país".

É contudo, a segunda classe de uso do vocábulo sob a forma de substantivo que nos dá a chave para a compreensão do termo em questão. O "Social", ainda segundo o Houaiss, é "o que pertence a todos; público, coletivo" e também "o que diz respeito ao bem-estar das massas, especialmente as menos favorecidas".

Não bastasse essa mudança semântica considerável, o caráter de substantivo é por si só revelador, já que para "social" ter se tornado $o$ "social" — referindo-se especificamente às "massas menos favorecidas" e não "ao conjunto dos cidadãos" - , significa que ele se tornou, em alguma medida, independente da sociedade como um todo.

Faz-se necessário examinar, portanto, o percurso histórico que permitiu que "social" deixasse de remeter à "sociedade", passando a qualificar apenas parte dela. Sustentamos que a substantivação do termo incorpora o caráter reificado que assumem nas ideias da classe dominante, as tais "massas" acima referidas. Parece-nos, portanto, oportuno analisar a maneira como o "social" tornou-se um corpo estranho à própria "sociedade" que, enquanto termo, passou ela mesma a ser sujeita a alterações de sentido, bem como a ser preterida por outros termos (em especial pela "comunidade", o que examinaremos ao final deste texto).

Para isso voltaremos ao momento histórico que marca a origem comum tanto desse "social" em sentido restrito quanto da "questão social", as revoluções europeias da primeira metade do século XIX.

$$
* \quad * \quad *
$$

A gênese do termo "questão social" se dá num momento-chave da história europeia, segundo nos informa José Paulo Netto:

Todas as indicações disponíveis sugerem que a expressão "questão social" tem história recente: seu emprego data de cerca de 170 anos. Parece que começou a 
ser utilizada na terceira década do século XIX e foi divulgada até a metade daquela centúria por críticos da sociedade e filantropos situados nos mais variados espaços do espectro político. (Netto, 2001, p. 152)

O ano de 1830 é, para todos os efeitos, a data em que o proletariado faz sua primeira aparição histórica enquanto ator político "em si" (o "para si" dar-se-ia apenas em 1848). Decorridas algumas décadas de industrialização em território francês, e dada a constrição imposta à grande burguesia pelo predomínio político dos grandes possuidores de terra no período da Restauração, a revolução voltava à ordem do dia na França.

Os vários setores da burguesia local se unificam e mobilizam o proletariado para instaurar, por meio de uma revolução, uma nova ordem que se materializaria na monarquia constitucional encabeçada por Louis Phillipe de Orléans, a Monarquia de Julho. Para prejuízo de boa parte das forças sociais envolvidas em tal transformação - em especial para o proletariado, que não aufere nenhum benefício da nova situação, o que, em parte, também vale para as camadas médias -, a nova hegemonia instaurada era de um setor burguês restrito ligado à grande indústria e em especial ao embrião de uma classe parasitária ligada ao capital portador de juros, a "aristocracia financeira".

O que subjaz a este pano de fundo político é aquilo que igualmente engendra a "questão social". Trata-se de um período marcado por dois condicionantes principais: Primeiramente, a elevação quantitativa exponencial da miséria e do pauperismo, ressaltada pelo contexto de aumento nunca antes visto das capacidades produtivas (Netto, 2001, p. 153). E, em segundo lugar, mas não menos importante, na transformação qualitativa das formas de protesto contra essas condições, agora protagonizadas por uma nova classe. Seria este o determinante-chave para o cunhar do novo termo. Neste sentido:

A designação desse pauperismo pela expressão "questão social" relaciona-se diretamente aos seus desdobramentos sociopolíticos. [...] Lamentavelmente para a ordem burguesa que se consolidava, os pauperizados não se conformavam com a sua situação: da primeira década até a metade do século XIX, seu protesto assumiu as mais diferentes formas, $[\ldots]$ configurando uma ameaça real às instituições sociais 
existentes. Foi a partir de uma eversão da ordem burguesa que o pauperismo designou-se como "questão social". (Idem, p. 154)

A "questão social" nunca foi, portanto, a questão da sociedade ou "referente ao conjunto da sociedade", mas sim, desde seu surgimento, foi a questão de um segmento desta, que, por ser potencialmente revolucionário, punha em risco o projeto de sociedade da burguesia, classe que em 1830 consolidava sua posição hegemônica. São, portanto, as implicações da questão operária que, "em seguida, o pensamento conservador designará com a fórmula aparentemente neutra de "questão social"" (Netto, 2004, p. 61), que fundamentam a nova expressão. Oculta sob o adjetivo "social" está a classe operária, sem a qual o termo deixa de fazer sentido, inclusive na maior parte dos usos contemporâneos da palavra. Se "social" e "operário" caminham juntos, e se, sem se confundir, estão intrinsecamente ligados, é possível compreender a razão pela qual '[c]uriosamente, a expressão 'questão social' emerge praticamente ao mesmo tempo em que surge, no léxico político, a palavra socialismo" (Netto, 2001, p. 152, n. 3). O "socialismo" é a formalização necessária no âmbito do discurso e das ideias políticas das pretensões do "social" de moldar uma nova sociedade, ou seja, é um reflexo das formas de rebelião política que assume o não conformismo dos setores subalternos da sociedade capitalista.

No texto de Marx, Las luchas de clases en Francia de 1848 a 1850, fica patente a natureza socialmente enraizada da flutuação semântica do termo "social". É, sobretudo, nas revoluções de 1848 que o vocábulo deixa de caracterizar apenas no discurso de uma consternada classe burguesa uma nova forma de pauperismo, sendo apropriado pelas próprias massas trabalhadoras nas suas palavras de ordem e reivindicações após a vitória da revolução de fevereiro:

Lo mismo que en las jornadas de julio habían conquistado luchando la monarquía burguesa, en las jornadas de febrero los obreros conquistaron luchando la república burguesa. Y lo mismo que la monarquía de julio se había visto obligada a anunciarse como una monarquía rodeada de instituciones republicanas, la república de febrero se vio obligada a anunciarse como una república rodeada de instituciones sociales. El proletariado de París obligó también a hacer esta concesión. (Marx, 2005, p. 133) 
Marx nos mostra que o termo "social" passa, a partir de certo ponto, a se identificar diretamente com as demandas da classe operária assim como "republicano" remeteria às reivindicações burguesas frente ao Antigo Regime. As "instituições sociais" apontariam, portanto, para além da república meramente burguesa.

Mas o que fundamentaria essa apropriação por parte do proletariado do vocábulo "social", se esse fora forjado pela classe burguesa? Argumentamos que desde os primórdios de seu uso, a batalha pela reivindicação do verdadeiro significado do "social" reside ora na sua particularização, ora na sua universalização pelas diferentes classes sociais em luta. À classe burguesa interessava, em um primeiro momento, universalizar abstratamente o significado do adjetivo "social", isto é, competia pulverizar a referência politicamente perigosa à classe operária num "social" que remetesse ainda ao conjunto da sociedade. Isto se explica, pois entre 1830 e 1848 a burguesia ainda sustenta a pretensão, objetivamente fundada, de incorporar, enquanto ente social particular, os interesses da sociedade como um todo, como havia feito na grande revolução de 1789. Nesse período, a classe burguesa ainda enxerga no avanço de seus interesses particulares o progresso do todo da sociedade. Isto não constituía falsa consciência, senão o reflexo de uma realidade que colocava na ordem do dia a expansão da revolução burguesa, rumo ao pleno desenvolvimento das relações sociais capitalistas.

Se essa utilização inicial do termo "social" no período citado correspondia, no plano do discurso, às pretensões universalizadoras de uma classe burguesa ainda revolucionária, justamente por ocultar o caráter de classe que possuíam os conflitos societários da época no seio do que havia sido o terceiro Estado, a situação se reverte quando o proletariado passa a reivindicar para si o status de classe depositária do interesse geral. Assim, é também da universalidade então inerente ao termo "social" da qual irá se nutrir o proletariado ao fazer deste o complemento de suas principais demandas: as instituições sociais, a emancipação social etc. Segundo José Paulo Netto (2004, p. 51):

Até então [1848], frequentemente as demandas dos segmentos vinculados ao trabalho apareciam indistintas dos projetos burgueses, subsumidas na aspiração 
revolucionária da igualdade, da fraternidade, e da liberdade. O trabalho, nos confrontos sociopolíticos, surgia também e ainda subordinado ao capital. É nas jornadas de 1848, que se patenteia o radical antagonismo entre ambos: quando se põe a exigência da república social, explicita-se o limite do mundo burguês.

Para opor as pretensões de classe universal do proletariado, bem como suas reivindicações sociais, a burguesia que no pós-1848 se revestiu de um ímpeto eminentemente conservador, precisou fazer a operação inversa à que havia realizado antes: se de início competia generalizar abstratamente os interesses das classes trabalhadoras, para que pudesse assumi-los como seus, agora era imperativo particularizar esses interesses, imputando-os a um setor pretensamente minoritário da sociedade, restringindo os males provenientes da "questão social" a anomalias sanáveis dentro da ordem vigente. Com essa viragem nas pretensões políticas da classe burguesa concomitante à entrada revolucionária do proletariado na cena histórica, restringe-se progressivamente o sentido do vocábulo "social", que não mais se confunde com o que "concerne ao todo da sociedade", passando a remeter apenas a um setor particular desta.

O destino do termo "sociedade" é outro caso digno de nota no percurso histórico do "social". Pois o progressivo esvaziamento do adjetivo "social" — que naturalmente advém do substantivo "sociedade" — não deixa este último termo incólume. A substantivação do "social", isto é, o processo que torna o "social" um objeto reificado, torna o uso da palavra "sociedade", por sua vez, um embaraço terminológico. O processo segundo o qual isso ocorre passa por um fenômeno diretamente relacionado aos acontecimentos de 1848-49 discutidos acima, isto é, à guinada decisiva que a burguesia dá rumo ao campo conservador.

No campo dos conflitos de classe isso equivaleu à opção da classe burguesa por uma aliança com seus antigos adversários — a aristocracia, os grandes possuidores de terra - para fazer frente às reivindicações do proletariado (muitas das quais estavam, à época, inscritas no programa da revolução burguesa 
e atendiam aos interesses dessa classe). No campo da ideologia, registram-se mudanças sensíveis: recorre-se às ideias sustentadas pelas classes remanescentes do Antigo Regime ou por aqueles que delas descendem, já que mesmo as ideias sustentadas pela burguesia do século XVIII se provam perigosas porque passíveis de apropriação pelo proletariado revolucionário. A figura emblemática desse câmbio nas pretensões da burguesia que ecoa no domínio ideológico é, sem dúvida, Alexis de Tocqueville.

Tocqueville é tido hoje como um dos principais autores liberais do século XIX, uma asserção indiscutível. O que é digno de nota, todavia, é que o pensador francês pertenceu à aristocracia e vivenciou o período da Revolução de 1789, "quando seus pais foram aprisionados e seu avô materno, o marquês de Rosambo, morreu na guilhotina em nome da liberdade, da igualdade e da fraternidade". (Barbu, Z. "Apresentação”, in Tocqueville, 1997, p. 12) Lembremos que o liberalismo havia sido a expressão máxima da burguesia no campo das ideias enquanto ainda se contrapunha às classes do Antigo Regime. Como é possível, portanto, que um dos grandes continuadores do liberalismo no segundo quartil do século XIX tenha sido um aristocrata?

O fenômeno-chave aqui é, sem dúvida, o esgotamento do papel revolucionário da burguesia que se revela em um período que já mencionamos, a saber,

[...] o ano de 1848 e os dias sangrentos de junho, a primeira ação independente da classe trabalhadora, que marcou de tal forma a ideologia da burguesia francesa, que, após este período, a ideologia burguesa deixou de desempenhar um papel progressista na França por um bom tempo. A ideologia se tornou adaptável, caminhando para a mera apologia da burguesia. (Lukács, 1964, p. 85; tradução do autor)

Assim, a centralidade que assume Tocqueville para o pensamento burguês é fruto de uma necessidade histórico-concreta que determinava que a crítica aristocrática da sociedade burguesa era preferível à sua crítica revolucionária por parte da classe operária. Em outras palavras, o imperativo de manutenção do status quo determinava que se estabelecesse uma identificação entre o universo feudal e o burguês contra o perigo vindo das massas, que se nutriam dos ideais da própria burguesia revolucionária. 
Isto se dá, no campo da ideologia, por meio de uma inversão na perspectiva histórica. No período revolucionário, o passado feudal foi julgado com os olhos do novo tempo em construção pela burguesia, e, portanto, era criticado pelo absoluto cerceamento da liberdade do indivíduo, pela forma arbitrária com que o poder era exercido por uma minoria restrita e pelo obscurantismo que dava coesão ao todo social. Em meados do século XIX, fica claro que tais críticas são passíveis de apropriação pelos elementos descontentes com a própria sociedade burguesa. A solução encontrada foi a revalidação da era feudal, com a recuperação parcial da ideologia que a sustentava.

Assim, a guinada conservadora da burguesia a partir de 1848-49 inicia-se com a crítica de seu próprio período revolucionário e dos ideais sem os quais não haveria ela própria rompido as amarras feudais e instaurado uma realidade histórica moldada à sua imagem. Condena-se de forma irrestrita o Iluminismo e sua incitação ao progresso, bem como o processo revolucionário de 1789, ou seja, instaura-se a crítica, que perdura até hoje, do progresso, da razão e das sublevações revolucionárias. ${ }^{3}$

O estatuto ideológico feudal é reabilitado, isto é, a liberdade em seu sentido aristocrático, a naturalização de uma divisão hierárquica da sociedade, bem como a crítica à soberania popular e ao sufrágio universal são todas apropriadas por uma burguesia tornada classe dominante. A ruptura entre a ordem capitalista e a ordem feudal se vê, portanto, escamoteada, o que demanda uma mudança de perspectiva sobre o caminhar da própria história. ${ }^{4}$ Assim, para a primeira burguesia, houve história, mas com sua chegada ao poder não haveria mais. A burguesia do período da decadência, por sua vez, extirpa por completo o devir da história ao negar a ruptura feudalismo/capitalismo, o que, por extensão, significa a negação de qualquer possibilidade de ruptura futura.

3. Cf. Lukács (2007, cap. 1).

4. O método de Marx já delimitava de maneira clara uma forma alternativa - efetivamente antagônica à adotada pela burguesia da época da decadência — de contrapor épocas históricas: "Nesta concepção teórica [a de Marx - V.S.], ao contrário das teses positivistas, é o mais complexo que esclarece o menos complexo — donde o estudo da ordem burguesa oferecer elementos para iluminar formações sociais anteriores" (Netto, 2004, n. 36). 
O recurso à análise da realidade capitalista vista à luz da realidade feudal é especialmente nítido em A. Tocqueville. Sua contribuição à tematização de nosso objeto centra-se sobre a noção de "associação", que ele irá analisar tornando patentes os traços descritos acima quanto ao pensamento da decadência. Em suas considerações, Tocqueville subverte este que é um termo caro à tradição revolucionária e à classe trabalhadora, imputando-lhe uma origem feudal num processo de apropriação e ressignificação que visa neutralizá-lo.

Segundo ele, a associação é uma instituição feudal, que quando praticada por aristocratas constituía processo simples e efetivo, já que se tratava da junção de uns poucos homens poderosos que reuniam em torno de si toda uma massa de pessoas a sua disposição para realizar um objetivo comum. Ao contrário do que acontece nas sociedades democráticas, a coesão é um dado imediato nas sociedades que Tocqueville denomina "aristocráticas", já que "os homens não precisam se unir para agir, porque são mantidos fortemente juntos" (Tocqueville, 2000, v. 2, p. 132).

O pensador francês toca num tema caro àqueles imbuídos da tarefa de reabilitar a ordem feudal, a saber, sua pretensa organicidade e coesão que se contrapõe ao individualismo exacerbado da sociedade capitalista. Ainda segundo o autor: "Cada cidadão rico e poderoso, nelas constitui como que a cabeça de uma associação permanente e forçada, que é composta de todos os que ele mantém em sua dependência e que faz concorrer para a execução de seus projetos" (Idem).

Essa linha de argumentação faz-se típica após os esforços iniciais de pensadores como Tocqueville e se caracteriza pela crítica a uma faceta da sociedade moderna acompanhada pela justificação das contradições da ordem feudal. Neste sentido, ao tomar essas duas realidades sociais como equivalentes para compará-las, perde-se o salto qualitativo que marca centralmente a revolução burguesa, isto é, o progresso frente às formações sociais anteriores. Pondera-se abstratamente prós e contras de cada etapa histórica como se existissem lado a lado: o preço da coesão e harmonia interna da sociedade feudal teria sido a dominação aristocrática; já o preço da liberdade da sociedade burguesa seria o individualismo que, contrariamente aos cânones da tradição liberal pré-decadência, é tido pelo pensador francês como negativo: "Nos povos democráticos 
[...] todos os cidadãos são independentes e fracos, não podem quase nada por si mesmos e cada um deles não poderia obrigar seus semelhantes a lhe prestar seu concurso. Assim, caem todos na impotência se não aprendem a se ajudar livremente" (Idem).

A alternativa estaria justamente na recuperação da associação, que seria, nas "sociedades democráticas", um verdadeiro imperativo dada a impotência do indivíduo isolado. O modelo para as associações de tipo novo, Tocqueville encontra nos Estados Unidos:

A primeira vez que ouvi dizer nos Estados Unidos que 100 mil homens tinham se comprometido publicamente a não fazer uso de bebidas fortes, a coisa me pareceu mais inconsequente do que séria [...]. Acabei compreendendo que esses $100 \mathrm{mil}$ americanos, assustados com o aumento da embriaguez à sua volta, tinham desejado patrocinar a sobriedade. Tinham agido precisamente como um grão-senhor que se vestisse muito singelamente a fim de inspirar aos simples cidadãos o desprezo ao luxo. É de crer que, tivessem esses 100 mil homens vivido na França, cada um deles teria se dirigido individualmente ao governo para pedir que este fiscalizasse os cabarés em toda a superfície do reino. (2000, p. 135)

A argumentação de Tocqueville é exemplar no que diz respeito à sugestão subreptícia da continuidade entre sociedade feudal e sociedade burguesa. Ao se associarem, os cidadãos norte-americanos incorporariam o espírito do grão-senhor, isto é, um mal das sociedades democráticas seria sanado pelo recurso ainda que inconsciente por parte dos 100 mil — a uma forma de organização a qual o pensador francês atribui uma origem aristocrática. $\mathrm{O}$ uso dos exemplos é tampouco acidental: o grão-senhor deseja defender, de todas as coisas, a modéstia; já o vício que a associação deseja contrapor na sociedade democrática é o alcoolismo. Há ainda a crítica irônica à maneira como os franceses lidariam com a questão - o recurso ao Estado — e que avança a noção cara a Tocqueville de que os indivíduos fracos e dispersos da sociedade burguesa estariam à mercê da tirania dos governantes. ${ }^{5}$

5. Há ainda neste trecho a defesa explícita da organização dada no âmbito da sociedade civil, contraposta favoravelmente ao Estado no que concerne à resolução dos problemas sociais. A atualidade desta argumentação 
Tocqueville é um dos primeiros representantes da viragem pós-1848 que faria do pensamento de viés aristocrático ou — guardadas suas diferenças romântico a principal arma ideológica da burguesia conservadora. Vale dizer que o recurso ao ideário de tipo aristocrático desempenhou sua função tanto mais efetivamente quanto mais pôde apresentar-se como uma crítica da sociedade capitalista. Assim, a crítica ao individualismo da sociedade burguesa (que parte de fundamentos objetivos) é alvo de soluções conservadoras inspiradas na organicidade e na suposta harmonia da sociedade feudal. Tal é a estratégia adotada de forma reiterada pela burguesia a partir de 1848 para fazer frente às propostas e reivindicações dos setores socialistas.

No que diz respeito ao nosso tema central, tanto a caracterização feita por Tocqueville da sociedade burguesa como uma aglutinação de indivíduos isolados, quanto a solução que advoga — as associações — negam a natureza social dos antagonismos inerentes a tal formação histórica, isto é, dissolvem as classes em uma pluralidade de indivíduos, fazendo do percurso histórico da classe trabalhadora rumo a sua emancipação a ação cega da igualdade transformada em potência abstrata. Se para o materialismo histórico a associação dos trabalhadores repousa sobre a base objetiva da classe, ou seja, é enraizada socialmente, para o aristocrata francês o "social" não pertence à sociedade; é antes um artefato contingente que depende da conjugação de interesses na associação.

Para encontrarmos os efetivos continuadores da tradição da qual Tocqueville é um dos inauguradores - a recuperação do pensamento aristocrático enquanto arma ideológica burguesa — devemos remeter à Alemanha. É lá que, não casualmente, a chama do pensamento de viés aristocrático perdura século XX adentro. É em terras alemãs onde a "sociedade" receberá o golpe de morte semântico que a relegaria ao segundo plano frente a outro termo, a "comunidade".

\footnotetext{
é inquestionável se pensarmos na retórica do chamado "terceiro setor" em tempos recentes. Uma análise do caráter premonitório das ideias de Tocqueville para o associativismo contemporâneo pode ser encontrada em Montaño (2007, p. 63-76).
} 
A vocação alemã para produzir o pensamento conservador aristocratizante não é acidental. Tem como base seu célebre atraso, tematizado por Marx ainda em 1843. Trata-se do dado mais fundamental da evolução histórica alemã na era moderna, a saber, o fato de que esta não consumou uma revolução burguesa "clássica" durante a qual teriam sido varridos os principais atores sociais do sistema feudal - a aristocracia — e, com ela, as formas de propriedade, os laços servis de dominação e demais barreiras ao desenvolvimento capitalista.

$\mathrm{Na}$ via clássica, uma vez restabelecido o devir histórico inteiramente sobre fundamentos burgueses após ter sido consumada a revolução, mesmo os membros restantes da antiga classe dominante que subsistem são inteiramente incorporados à sociedade capitalista. É por essa razão que Tocqueville, um sobrevivente daquela que foi a revolução burguesa por excelência, opõe à ordem capitalista apenas a ideia do Antigo Regime como alternativa, e não sua estrutura social (é isto que o permite enxergar mesmo na mais moderna das nações - os Estados Unidos — características de "tipo" aristocrático). Especialmente após a Revolução de Julho de 1830, a presença dos remanescentes da aristocracia na figura dos legitimistas do Partido da Ordem na França não apresenta uma alternativa real à dominação burguesa. Ao contrário, esses estão integralmente incorporados à lógica do sistema capitalista, são uma aristocracia "aburguesada".

AAlemanha teve uma unificação nacional tardia produzida sem uma ruptura histórica violenta com o passado, o que significou a sobrevivência de uma forte aristocracia representada, sobretudo, pelos grandes possuidores de terra a leste do rio Elba, os junker. Não por acaso, foi solo adequado para a formação de uma ideologia que aponta para o passado, além de ser - graças ao frenético ritmo de desenvolvimento capitalista em solo alemão nas últimas décadas do século XIX — altamente funcionalizável pela ordem capitalista. O mais marcante dos efeitos produzidos por essa trajetória histórica particular é que os traços aristocráticos não se limitam ao pensamento de autores diretamente ligados à aristocracia - como era o caso de Tocqueville na França. Ao contrário, podem ser encontrados em autores dos mais diversos extratos sociais, mesmo nos mais decididamente burgueses ou até em pensadores ligados à esquerda operária. É o caso do autor que iremos tematizar logo adiante, Ferdinand Tönnies. 
Antes, porém, convém abordar uma faceta da língua alemã que oferece um interessante subsídio para as hipóteses deste trabalho. Se nas línguas latinas a mudança semântica do termo "social" foi acompanhada por sua substantivação, isto é, uma alteração de classe gramatical que indicou que aquilo que se refere à sociedade se transformou em algo independente desta última, no alemão tal câmbio gerou dois vocábulos diferentes. Há, a exemplo do português, um substantivo Gesellschaft (sociedade) que partilha do radical do adjetivo gesellschaftlich, de forma semelhante à sociedade/social.

Todavia, a entrada do movimento operário no palco político das lutas de classes introduz não a substantivação do termo gesellschaftlich, mas uma nova palavra: o adjetivo sozial. A “questão social” em alemão, por exemplo, já nasceu como "soziale Frage". Analogamente, nas palavras de Marx, citadas neste trabalho, a república de fevereiro de 1848 "se vio obligada a anunciarse como una república rodeada de instituciones sociales", isto é, "als eine Republik, umgeben von sozialen Institutionen". ${ }^{6}$

Este fenômeno linguístico não se deve à pretensa vocação da língua alemã para a filosofia, como a caracterizou certa vez Heidegger, mas ao atraso alemão segundo o qual as questões de cunho político associadas ao "social" são incorporadas com um novo termo, a despeito da existência de uma palavra passível de traduzi-lo (gesellschaflich). Assim, o "social" francês é apenas ligeiramente germanizado (no século XIX, apenas na pronúncia, mantendo o "c" original, e posteriormente assumindo uma nova grafia — sozial), o que imputa um caráter exógeno àquilo que é exprimido pelo termo no que diz respeito à realidade alemã. No universo linguístico alemão, os problemas sociais em nenhum momento se confundem com os problemas da sociedade, seriam antes fenômenos externos à tradição germânica introduzidos talvez com a chegada da Zivilisation, também ela um fenômeno estrangeiro (cf. Mann, 1975). O que nos leva ao

6. Deve-se ressaltar que não há uma cisão semântica completa entre os adjetivos gesellschaftlich e sozial. O último é admitido para denominar, de acordo com o Dicionário eletrônico da Academia de Ciências de Berlin-Brandenburg (disponível em: <www.dwds.de>), "aquilo que é relativo à correlação, à vida conjunta dos homens". Contudo, sozial também diz respeito "à estrutura econômica e política de uma dada sociedade", "ao pertencimento dos homens a diferentes classes, grupos ou extratos no interior da sociedade" e finalmente, "aos benefícios voltados à melhoria das condições de vida e trabalho, à assistência cultural e de saúde dos trabalhadores ou membros da sociedade sob penúria material". As referências do texto original de Marx estão disponíveis em: <http://www.mlwerke.de/me/me07/me07_012.htm>. Acesso em: 10 fev. 2014. 
ponto que discutíamos anteriormente, a saber, a incorporação do pensamento aristocrático pela ideologia burguesa ciosa de frear o devir histórico que aparenta apontar para sua dissolução enquanto classe.

Como já dissemos, o progressivo distanciamento entre "social" e "sociedade" resvalou de forma decisiva sobre este último vocábulo. O parentesco etimológico entre o repugnado "social" e a "sociedade" é por demais evidente para ser ignorado, o que pode levar a embaraços para o pensamento burguês: como dizer, por exemplo, que pertencemos à sociedade mas não ao "social"?

É Ferdinand Tönnies (1855-1936) que dará uma solução amplamente utilizada desde então a esse dilema em seu estudo clássico Comunidade e sociedade, de 1887. Pertencente à primeira geração de sociólogos propriamente ditos da academia alemã, Tönnies abre sua obra enunciando o seguinte propósito:

Las distintas voluntades humanas mantienen entre sí múltiples relaciones. [...] Este estudio tendrá por objeto de investigación solamente las relaciones de afirmación recíproca. [...] El grupo formado por el tipo positivo de relación recibe el nombre de ligamen (Verbindung) cuando se concibe en calidad de ser o cosa que actúa como unidad tanto hacia su núcleo como hacia su exterior. La relación misma, así como la asociación resultante, se concibe aquí bien como ida orgánica y real — característica que es esencial en la Gemeinschaft (comunidad) —, bien como estructura imaginaria y mecánica — es decir, el concepto de Gesellschaft (sociedad o asociación). (Tönnies, 1979, p. 27)

Eis que o embaraço antes provocado é dissolvido no uso de dois termos, qualitativamente díspares, para denominar a "unidade de distintas vontades humanas": "comunidade" e "sociedade", a primeira denotando o vínculo essencial e orgânico entre os homens e a última uma estrutura meramente artificial e contingente. Já nestas palavras iniciais se faz nítida a contraposição de uma concepção aristocrática de coletividade a uma concepção burguesa desta. À maneira de Tocqueville, essa síntese se reveste de uma crítica à sociedade capitalista, o que, no caso de Tönnies envolve o uso, com alguma constância, de linguagem ou de conceitos derivados diretamente de Marx. ${ }^{7}$

7. Sobre tal procedimento, Lukács afirma o seguinte: "Tönnies es el primer sociólogo alemán que no rechaza a limine a Marx, sino que trata de reelaborarlo, poniéndolo a contribución para sus fines burgueses" (Lukács, 1959, p. 523). 
Mais uma vez, e também em linha com o pensador francês citado, são os exemplos que traem o juízo positivo do autor acerca da ordem feudal que pautará toda a obra em questão. Discorrendo sobre as relações forjadas na comunidade, o autor afirma o seguinte:

Y ocurre que esto constituye una tendencia inherente natural: a una fuerza y poder superiores corresponde también una capacidad mayor de ayuda. Si tal intención o voluntad existe, será tanto más fuerte y decidida a causa del sentimiento de poder que conlleve. Con lo que nos encontramos, sobre todo en el terreno de las relaciones físico-orgánicas, con una ternura instintiva e ingenua del fuerte por el débil, [...] la ternura corresponde a la reverencia, o, en un menor grado de intensidad, la benevolencia al respeto; representan éstos los dos polos del sentimiento en que se basa la Gemeinschaft [a comunidade - V. S.], en caso de que exista una diferencia definida de poder. (Tönnies, 1979, p. 38-39)

Sob a forma de uma tipificação atemporal se oculta uma elegia ao universo caracteristicamente feudal das relações de dependência e servidão. O que é mais interessante nas análises dotadas deste viés é o fato de que as referências ao passado aristocrático são desprovidas de historicidade, enquanto imputa-se aos tempos burgueses, isto é, a constituição da sociedade, um caráter contingente, precário. Desta maneira, tal qual a virtude da associação descrita por Tocqueville estariam presente, ainda que em formas diversas, tanto nas formações sociais medievais quanto na sociedade burguesa, a "ternura" e a "benevolência", características naturais dos homens em posição de poder através dos tempos. Sob essa luz, o capitalismo aparece como um arranjo antinatural e, portanto, problemático.

En el sentido más general podemos hablar de una Gemeinschaft (comunidad) que comprenda el conjunto de la humanidad, tal y como la Iglesia quiere ser considerada, por ejemplo. Pero la Gesellschaft (sociedad) humana se concibe como mera coexistencia de individuos independientes unos de otros. [...] En oposicion con la Gemeinschaft, la Gesellschaft (asociación) es transitoria y superficial. A este tenor, la Gemeinschaft (comunidad) debiera ser entendida como organismo vivo y la Gesellschaft (asociación) como un artefacto, un añadido mecánico. (Tönnies, p. 28-29) 
Essa combinação entre o atemporal e o contingente leva, no entanto, a uma solução conservadora, já que as críticas ao capitalismo em momento algum colocam sua existência em questão. $\mathrm{O}$ fato de que comunidade e sociedade existam juntas leva a crer que basta reforçar e ampliar os sentimentos e ações relacionadas à primeira para que sejam parcialmente neutralizados os males trazidos à tona pela segunda. A despeito de seus muitos males, a sociedade, juntamente com o capitalismo, aparece na obra de Tönnies como tendência irrefreável.

Na obra Desenvolvimento da questão social — com primeira edição em 1907, ampliada em 1919 - Tönnies se propõe uma análise histórica ampla da "questão social" (que não constringe com aspas) ligando-a diretamente ao surgimento e consolidação da sociedade. Eis sua definição: "Entendemos por "cuestión social" el complejo de problemas que derivan de la cooperación y convivencia de classes, estratos y estamentos sociales distintos, que forman una misma sociedad, pero están separadas por hábitos de vida y por sua ideologia y visión de mundo" (Tönnies, 1927, p. 13).

Nesse trecho patenteia-se o sincretismo que caracteriza a produção de Tönnies. A "questão social” adviria dos problemas de "convívio" entre as classes, mas também entre estratos e estamentos, os quais estariam opostos não só pela ideologia que sustentam, mas igualmente pela visão de mundo da qual seriam portadores. Nos defrontamos com uma teoria social que procura fundir elementos da sociologia acadêmica alemã de fins do século XIX com as ideias de Karl Marx. ${ }^{8}$ Trata-se, evidentemente, de uma mistura instável. No caso de Tönnies, ela é marcada pelas tendências aristocráticas já mencionadas, mas também por sensibilidades de esquerda que remetem à proximidade do autor com a social-democracia alemã. Assim, a despeito de sua incompatibilidade intrínseca, tal combinação abre espaço, entre outras coisas, para momentos de efetiva crítica da sociedade capitalista. Isto se evidencia no tratamento estendido pelo autor aos desdobramentos agrários da "questão social", já que lhe

8. Algo que também se manifesta no seguinte trecho: "Con lo dicho se relaciona la evolución de la cuestión social, cuya fuerza motora es precisamente la contradicción y lucha de clases dentro de la nueva sociedad, del Estado y de la consciencia coletiva [?!]”. (Tönnies, 1927, p. 38; grifos nossos). 
permite ligar o termo que intitula sua obra à classe trabalhadora, ${ }^{9} \mathrm{e}$, ao mesmo tempo, criticar o caráter meramente formal da liberdade do trabalhador sob o capitalismo:

[...] la explotación latifundiaria necesita disponer de una clase proletaria lo más numerosa posible, y tanto mejor podrá disponer de ésta cuanto más la separe de la propiedad del suelo, y de los restantes medios de producción, convirtiéndola de una clase de pequeños agricultores, en una masa meramente jornalera. Y si bien formalmente la última es libre, cosa que no siempre ocurre en la primera, es lo cierto que económicamente una y otra son materialmente dependientes; más cuando se trata de obreros absolutamente libres, propiamente jornaleros. (Tönnies, 1927, p. 26)

Mais uma vez é possível perceber a sutil elegia dos tempos feudais que acompanha a crítica à sociedade capitalista. $\mathrm{O}$ proletariado rural, ainda que possivelmente mais livre que o pequeno agricultor preso à terra, é talvez mais dependente materialmente do latifundiário, isto é, do antigo senhor.

É importante ressaltar que a crítica produzida não perde necessariamente sua validade por emanar de uma perspectiva aristocrática e que esta nem sempre vem acompanhada por um olhar nostálgico para épocas anteriores. ${ }^{10} \mathrm{Con}$ tudo, se não são necessariamente elogiosos para o passado, são frequentemente ambíguos em relação a este, ambiguidade que só se vê reiterada pela ausência de uma proposta clara ou unívoca para a sociedade futura. Não por acaso, e por vezes em franca oposição à postura individual dos teóricos por elas responsáveis, ${ }^{11}$ tais ideias deram lastro a concepções ultraconservadoras da política e da realidade social.

9. “[...] la cuestión social que hoy nos ocupa [se refiere] especialmente al trabajo industrial. La cuestión social es, pues, principalmente, la cuestión obrera, y sobre todo, la cuestión obrera industrial. Sólo en segundo término viene la cuestión obrera agrícola" (Tönnies, 1927, p. 38; grifos nossos).

10. Cf. Löwy e Sayre (1995) e Löwy (1990).

11. Como já afirmamos, Tönnies é um exemplo nítido de atitude intelectual que possui parentesco com as sínteses conservadoras, mas cuja honestidade e posicionamento político o levaram para o campo oposto. Em meio à ascensão do nacional-socialismo em terras alemãs, Tönnies se junta ao Partido Social-Democrata: “[...] em 1930, Tönnies abandona sua concepção anterior de que um acadêmico deveria posicionar-se perante 
Se nos concentramos no século XIX e início do XX, não pretendíamos ignorar o fato de que batalhas terminológicas continuam a ser disputadas encarniçadamente nos tempos atuais. Entendemos apenas que se deve atentar para as lições já proferidas pelo pensamento crítico para desafios como esses: como proceder se um termo é cunhado por setores conservadores para abranger um conjunto de fenômenos sob perspectiva enviesada, mistificadora? Tal é a pergunta que se colocaram tanto aqueles que se depararam com a tarefa de desconstruir a "questão social" quanto aquela com que se defronta os que hoje encaram termos quiçá mais problemáticos como "empreendedorismo", "responsabilidade social", "situação de risco/vulnerabilidade social" etc.

Mas vale aqui uma nova referência as palavras de Marx: "Mudando-se o nome não se muda a coisa. [...] Falando da oferta e da demanda das coisas, não se fala da oferta e da demanda do nome das coisas" (Marx, 2009, p. 100).

Não devemos procurar disputar nem ter a ilusão de poder vencer esses conflitos no plano do discurso. Não podemos, todavia, abandonar esse campo como pura mistificação (é esta, penso, a lição dos pensadores críticos do Serviço Social). Há que se perguntar a origem e a trajetória dos termos com os quais lidamos, ponderar os desdobramentos políticos de sua utilização e, especialmente, retribuir mesmo a peça da mais franca apologética burguesa com uma análise adequada. Este artigo pretendeu ser uma pequena contribuição neste sentido.

\section{Recebido em 25/2/2014 - Aprovado em 2/6/2014}

\footnotetext{
os problemas sociais e políticos prementes, mas não se envolver com a política partidária: ele aderiu abertamente ao Partido Social-Democrata" (Cahnman, 1973, p. 285; tradução do autor).
} 


\section{Referências bibliográficas}

CAHNMAN, W. J. Ferdinand Tönnies: a new evaluation. Leiden: Brill, 1973.

DIDEROT, D.; D’ALEMBERT, J. L. R. Verbetes políticos da enciclopédia. São Paulo: Discurso/Unesp, 2006.

HOBBES, T. [1651] Leviathan. Indianapolis/Cambridge: Hackett, 1994.

LOCKE, J. [1689] Dois tratados sobre o governo. São Paulo: Martins Fontes, 2001.

LÖWY, M. Romantismo e messianismo. São Paulo: Perspectiva/Edusp, 1990.

; SAYRE, R. Revolta e melancolia. Petrópolis: Vozes, 1995.

LUKÁCS, G. [1938] Marx y el problema de la decadencia ideológica. Mexico: Siglo XXI, 1981.

. Ojovem Marx e outros escritos de filosofia. Rio de Janeiro: Ed. da UFRJ, 2007.

. Studies in European realism. New York: Grosset \& Dunlap, 1964.

. [1954] El asalto a la razón. Buenos Aires: Fondo de Cultura Económica, 1959.

MANN, T. [1918] Considérations d'un apolitique. Paris: Grasset, 1975.

MARX, K. [1867] O capital. São Paulo: Abril, 1988. v. 1.

. [1850] Las luchas de clases en Francia de 1848 a 1850. Buenos Aires:

Luxemburg, 2005.

. [1847] Miséria da filosofia. São Paulo: Expressão Popular, 2009.

. Grundrisse. New York: Random House, 1973.

; ENGELS, F. [1848] Manifesto do Partido Comunista. Bragança Paulista:

Editora São Francisco, 2003.

MONTAÑO, C. Terceiro setor e questão social. São Paulo: Cortez, 2007.

NETTO, J. P. Capitalismo monopolista e Serviço Social. São Paulo: Cortez, 2001. . Marxismo impenitente. São Paulo: Cortez, 2004.

TOCQUEVILLE, A. de. [1856] O antigo regime e a revolução. Brasília: UnB, 1997. . [1835-1840] A democracia na América. São Paulo: Martins Fontes, 2000. v. 2.

TÖNNIES, F. [1887] Comunidad y asociación. Barcelona: Península, 1979. [1913] Desarrollo de la cuestión social. Barcelona: Labor, 1927. 